\title{
Linear Basal Cell Carcinoma: A Case Report
}

\author{
Yuko Ichinokawa ${ }^{\mathrm{a}}$ Akiko Ohtuki ${ }^{\mathrm{a}}$ Mariko Hattori ${ }^{\mathrm{a}}$ \\ Hiroko Sadamasa ${ }^{a}$ Masataro Hiruma ${ }^{a}$ \\ Toshiharu Matumoto ${ }^{b}$
}

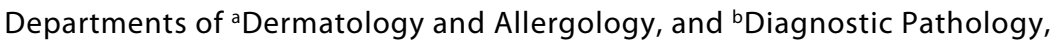
Juntendo University Nerima Hospital, Tokyo, Japan

\section{Key Words}

Basal cell carcinoma, infiltrative and nodular types - Linear basal cell carcinoma .

Periocular region

\section{Abstract}

Basal cell carcinoma (BCC) presents with diverse clinical features, and several morphologic and histologic variants of BCC have been reported [Sexton et al.: J Am Acad Dermatol 1990;23:1118-1126]. Linear BCC was first described as a new clinical subtype in 1985 by Lewis [Int J Dematol 1985;24:124-125]. Here, we present a case of linear BCC that we recently encountered in an elderly Japanese patient, and review other cases reported in Japan.

\section{Case Report}

A 79-year-old woman was referred from a local clinic to our department in October 2010 for treatment of a lesion on her eyelid. Approximately 3 years earlier she had developed a small, roundshaped, black nodule on her left lower eyelid. The nodule had gradually extended in one direction toward the proximal side of the inner canthus.

She presented with a small, black nodule on the lateral side of her lower eyelid and another small, black nodule on the inner canthus. A linear lesion, $3 \times 20 \mathrm{~mm}$ in size, was seen extending from the right lateral to the medial infraorbital crease, with a scar-like appearance (fig. 1). Dermatoscopic examination revealed arborizing vessels, multiple blue-gray globules and large, blue-gray ovoid nests (fig. 2 ). Laboratory tests showed no abnormalities in hematological parameters, and both family history and personal medical history were unremarkable.

The tumor region was completely excised with a 3-mm margin. Histologically, in the 2 nodules, nests of atypical cells resembling epidermal basal cells were present in the dermis, and some of the nests were contiguous with the epidermis. In the lateral nodule, the nests mainly appeared in a nodular arrangement, while in the median nodule, infiltrative arrangement was mainly noted. Subsequently, basal cell carcinoma (BCC), nodular type in the lateral lesion and infiltrative type in the median lesion, 
was diagnosed. In the linear area between the 2 nodules, the presence of BCC nests was sporadically noted, thus the typing of BCC was not performed in that area (fig. 3 , fig. 4 ). On the basis of these clinical and histopathological findings, namely both nodular and infiltrative BCC, the patient was diagnosed as having linear BCC.

\section{Discussion}

In 2011, Al-Niaimi and Lyon analyzed 37 reported cases of linear BCC retrieved in an exhaustive literature search [3]. In all of the cases described, linear BCC appeared to extend preferentially in one direction, resulting in a characteristic morphology of a linear lesion with straight edges and a length much longer than the width (with a ratio of at least 3:1). From their review of those cases, Al-Niaimi and Lyon made the following observations about linear BCC: (1) the most frequently affected sites are the periorbital area and the neck (68\%), and (2) tumor cell infiltration (subclinical extension) is more easily seen than the clinical lesion. Al-Niaimi and Lyon concluded that linear BCC should be considered a distinct clinical morphological variant of BCC [3].

From our findings, we believe that this subtype of BCC is genuinely rare, but may be underreported due to its underrecognition as a distinct presentation of BCC [4]. The clinical manifestation of this disease as a linear form may be due to the fact that the dermis of the eyelid is thin and quite poor in fibrous components [5]; thus, the lesion might expand along wrinkles, resulting in the linear shape $[6,7]$.

We searched Japana Centra Revuo Medicina for Japanese-language reports of linear BCC. We encountered only 10 cases of linear BCC reported in Japan from 1983 to 2011 [8-10]. Including the present case, the patients consisted of 4 men and 7 women, ranging in age from 28 to 88 years (mean: 70). The duration of the lesion before excision ranged from 6 months to 20 years (mean: 6.2 years).

The most common site for linear BCC was the periocular region. The locations of linear BCC onset were the lower eyelid (4 cases), underneath the eyebrow ( 1 case), nasolabial groove (1 case), and the forehead (1 case). In the remaining 4 patients with linear BCC, the lesion was found on the axilla ( 2 cases), the palm ( 1 case), or the inguinal region (1 case). In all cases, the tumor appeared clinically as a linear lesion along a wrinkle. Histopathological classifications included solid type (4 cases), solid + superficial type ( 2 cases), and superficial type ( 1 case). Histologic subtypes were not reported in the remaining 4 cases. None of the tumors were classified as morphemic (a high-risk type), and tumor recurrence was not observed in any of the cases reported in Japan.

In patients with small nodules assuming a linear form around the eyes, linear BCC should be considered in the differential diagnosis. In treating linear BCC, it is essential to resect the lesion carefully to prevent tumor recurrence, bearing in mind that subclinical extension of tumor cells is sometimes more extensive than the clinical lesion. 


\begin{tabular}{r|l|l|l}
$\begin{array}{c}\text { Case Reports in } \\
\text { Dermatology }\end{array}$ & $\begin{array}{l}\text { Case Rep Dermatol 2011;3:142-146 } \\
\text { DOI: } 10.1159 / 000330295\end{array}$ & Jully 12, 2011 & $\begin{array}{l}\text { I 2011 S. Karger AG, Basel } \\
\text { ISSN 1662-6567 } \\
\text { www.karger.com/cde }\end{array}$ \\
\hline
\end{tabular}

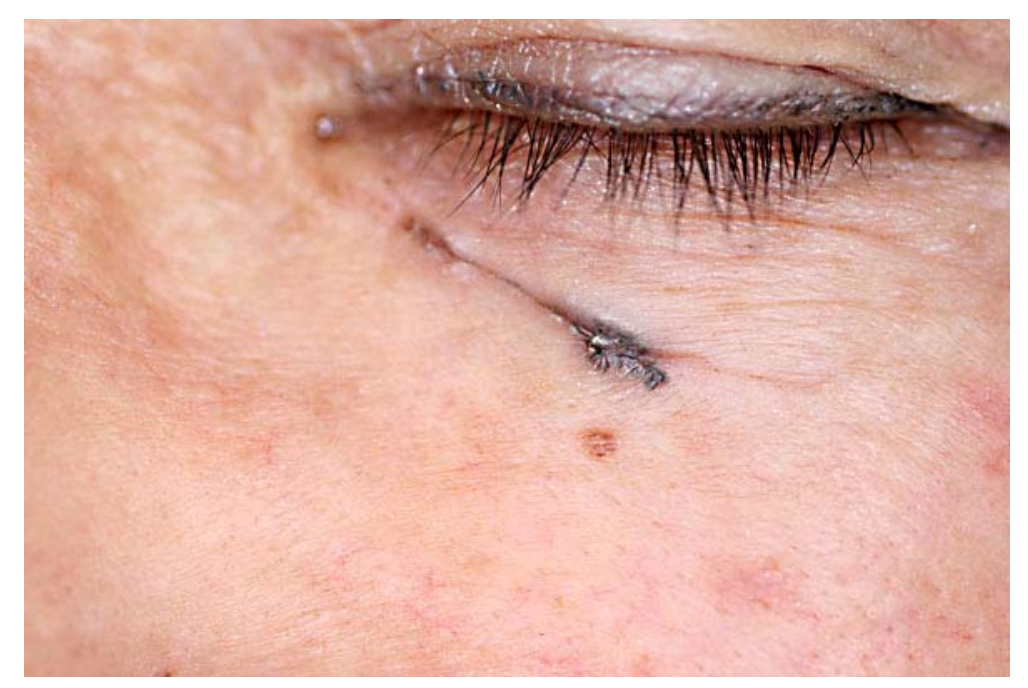

Fig. 1. A small, black nodule can be seen on the lateral side of the lower eyelid and another small, black nodule on the inner canthus. Linear black spots were noted along the Langer's lines as if connecting the two nodules.

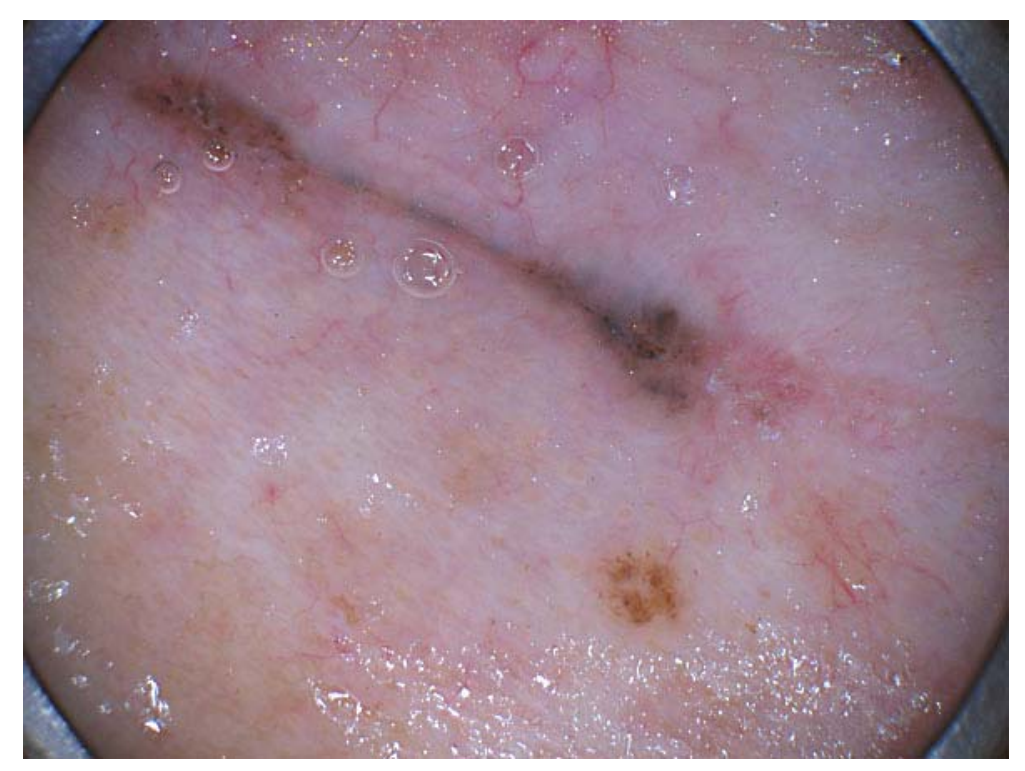

Fig. 2. Dermatoscopic examination revealed arborizing vessels, multiple blue-gray globules and large, blue-gray ovoid nests. 


\begin{tabular}{r|l|l|l}
$\begin{array}{c}\text { Case Reports in } \\
\text { Dermatology }\end{array}$ & $\begin{array}{l}\text { Case Rep Dermatol 2011;3:142-146 } \\
\text { DOI: } 10.1159 / 000330295\end{array}$ & Jully 12, 2011 & $\begin{array}{l}\text { I 2011 S. Karger AG, Basel } \\
\text { ISSN 1662-6567 } \\
\text { www.karger.com/cde }\end{array}$ \\
\hline
\end{tabular}

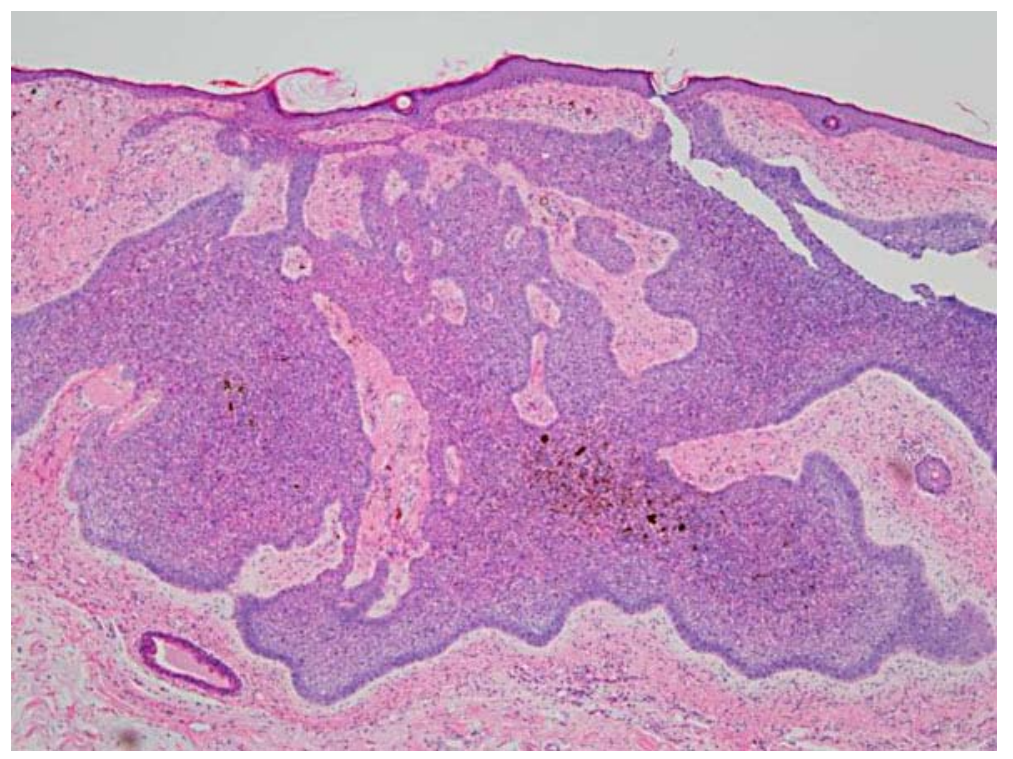

Fig. 3. Biopsy specimens (H\&E staining) demonstrating typical nodular and infiltrative types of linear BCC. Nodular tumor with peripheral palisading.

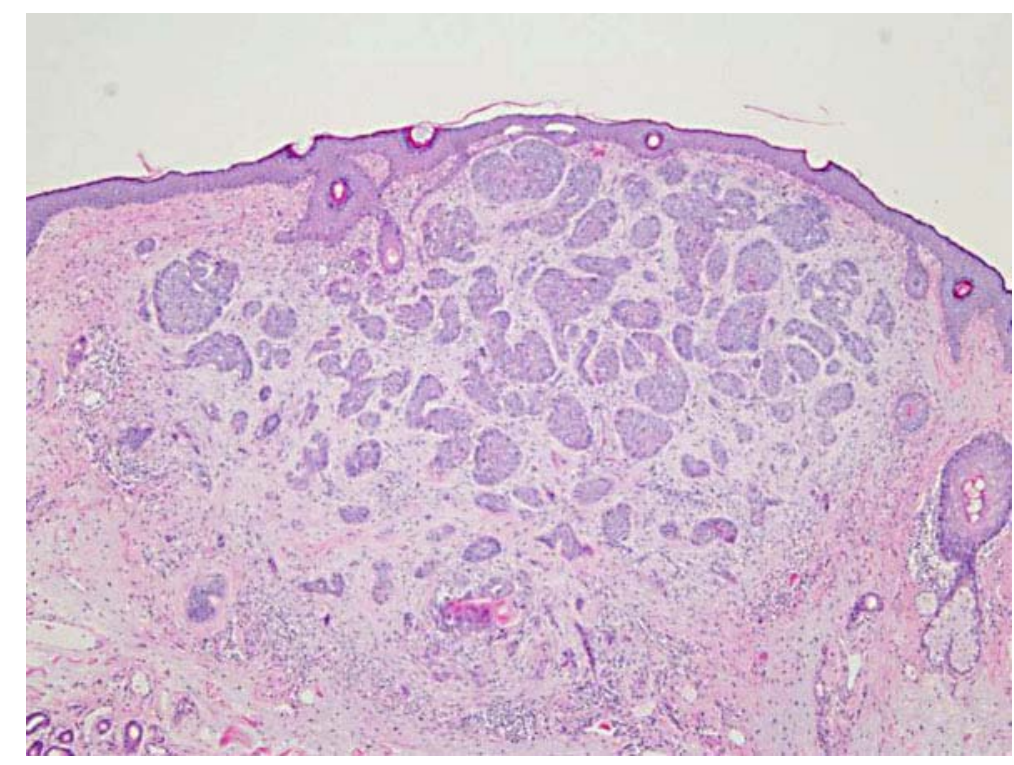

Fig. 4. Infiltrative tumors infiltrating deep into the dermis. 


\section{References}

1 Sexton M, Jones DB, Maloney ME: Histologic pattern analysis of basal cell carcinoma. Study of a series of 1,039 consecutive neoplasms. J Am Acad Dermatol 1990;23:1118-1126.

2 Lewis JE: Linear basal cell epithelioma. Int J Dematol 1985;24:124-125.

-3 Al-Niaimi F, Lyon CC: Linear basal cell carcinoma: a distinct condition? Clin Exp Dermatol 2011;36:231-234.

4 Van Scott EJ, Reinertson RP: The modulating influence of stromal environment on epithelial cells studied in human autotransplants. J Invest Dermatol 1961;36:109-131.

5 Peschen M, Lo JS, Snow SN, Mohs FE: Linear basal cell carcinoma. Cutis 1993;51:287-289.

-6 Smeets NW, Krekels GA, Ostertag JU, Essers BA, Dirksen CD, Nieman FH, Neumann HA: Surgical excision vs. Mohs' micrographic surgery for basal cell carcinoma of the face: randomised clinical trial. Lancet 2004;364:1766-1772.

7 McGrath JA, Uitto J: Anatomy and organization of human skin; in Burns T, Breathnach SM, Cox N, Griffiths CE (eds): Rook's Textbook of Dermatology, ed 8. Oxford, Blackwell Science, 2010, vol 1, pp 3.1.

8 Yamada D, Minamiya Y, Sugaya M, Tamaki T: Linear basal cell carcinoma: a case report. Rinsho Derma 2010;50:1255-1257.

9 Ohji M, Hori A: Eccrine poroepithelioma. Rinsho Derma 1982;24:532-533.

10 Miyazaki K, Inatomi T, Mekata C, Henmi A, Yanai S: So-called 'Linear Basal Cell Carcinoma' occurred on the eyebrow - can it be a definite disease? Rinsho Derma 2010;52:1447-1450. 